\title{
THE EFFECT OF LEADERSHIP STYLE OF PRINCIPLES AND PERFORMANCE OF TEACHERS TOWARD THE QUALITY OF PRIMARY SCHOOLS IN JATILAWANG SUB- DISTRICT OF BANYUMAS REGENCY
}

\author{
Pamujo \\ Universitas Muhammadiyah Purwokerto \\ Purwokerto, Indonesia
}

\author{
Kurnia Subiyanti \\ Purwokerto, Indonesia
}

\begin{abstract}
The study was initiated from the preliminary observation in one of the primary schools in Jatilawang subdistrict. There was the barrier of the primary schools' quality that was affected by the principles' leadership style and the teachers' performance. After being related to the quality theory, actually those two elements were the factors that affected the quality. The study was aimed at: 1) finding out the effect of the principles' leadership style toward the primary schools' quality in Jatilawang sub-district; 2) finding out the effect of the teachers' performance toward the primary schools' quality; 3) finding out the effect of the principles' leadership style and the teachers' performance toward the primary schools' quality. It was survey quantitative study. The subjects were the principles and the primary school teachers. The objects were the effect of the principles' leadership style and the teachers' performance toward the primary schools' quality. The questionnaires were used to collect the data. The result of the first hypothesis revealed that there was the significant effect of the principles' leadership style toward the primary schools' quality. The result of the second hypothesis revealed that there was the significant effect of the teachers' performance toward the primary schools' quality. The result of the third hypothesis revealed that there was significant effect of the principles' leadership style and the teachers' performance toward the primary schools. Therefore, it can be concluded that the principles' leadership style and the teachers' performance affect the primary schools' quality.
\end{abstract}

Keywords: schools' quality, principle’s leadership style, teachers' performance

\section{A. The Background Study}

Improving the quality of education is a requirement that cannot be delayed therefore the efforts to achieve success in improving the quality of education need to be handled seriously. The success of development is determined by the existence of qualified human resources mainly generated through quality education as well, so that the education building and development should be optimized starting from the basic education.

The issue of the quality of education in Indonesia is still far from being expected if it is compared with the quality of education in other countries. The results of the survey of Program for International Study Assessment (PISA) in 2012 (Tempo, 2013 [Online]) reveal that Indonesia is put as one of the lowest ranked countries in achieving the quality of education. The mean score of Indonesian students ranks second lowest of 65 countries.
Another study which states that education in Indonesia is still low is a study from Political and Economical Risk Consultancy (PERC) in 2005 (Tempo, 2013 [Online]). It illustrates how low the quality of education in Indonesia is. The PERC study states that education in Indonesia is ranked on the $12^{\text {th }}$ out of 12 countries in Asia. Indonesia is in the most distant position under Malaysia, Singapore, Brunei, Thailand and Philippines (Tempo, 2013 [Online]).

The declining quality of education in Indonesia is specifically seen from a macro perspective due to the poor national education system of Indonesia (Tempo, 2013 [Online].) The quality of education in Indonesia is one of the central issues within the framework of today's critical pedagogical discourse. The issue of quality of education is related to the quality of teachers and education personnel (principals, supervisors), teaching curriculum, teaching 
methods, teaching materials, teaching aids, and school management. These six elements are interrelated in an effort to improve the quality of teaching and learning which culminates in improving the quality of education.

The common problems that cause the quality of education in Indonesia is low can be resulted from the sources that affect the quality of education. Sallis (2012: 30) mentions many sources in education that affect quality improvement, such as good building facilities, outstanding teachers, high moral values, satisfactory test results, specialization or vocation, parental encouragement, business and local communities, abundant resources, advanced technology applications, good and effective leadership, attention to learners and students, an adequate curriculum, or a combination of these factors. Based on the elements that affect the quality above, the principal and teacher leadership conditions become one of the elements affecting the quality of education.

Based on a survey sample conducted by researchers in August 2014in SDN3 Tinggarjaya, Jatilawang sub-district, and in April 2015 with a teacher of SDN 4 Jatilawang, there are several problems that are often encountered and related to classroom teachers and principals in performing their duties and functions as teacher.

Based on the above background,the research on the quality of primary schoolsthat is influenced by two elements of principals' leadership style and teachers' performance is considered to benecessary to conduct. This research is expected to be able to answer the problematics that exist in Jatilawang sub-district, especially on the problem of improving the quality of elementary school which is seen from two elements that is principal leadership style and teacher performance.

\section{B. Research Methodology}

The quantitative research was used as the research approach. According to Sugiyono (2013: 8), quantitative research method can be interpreted as a research method based on the philosophy of positivism, is used to examine the population or a particular sample, data collection using research instruments, quantitative/ statistical data analysis, in order to test the hypothesis that has set.

The research was conducted at State Primary School in Jatilawang Sub-district of Banyumas Regency that consisted of 36 primary schools. The place of study will be taken based on the samples in Jatilawang sub-district because of the limited research and the area at the sub- district. The study was conducted from 7 to 25 March 2016 in the academic year of 2015/2016.

The subjects of this research were two principals and teachers of primary schools in Jatilawang sub-district of Banyumas regency. The objects of his research were the effect of principals' leadership style and teachers' performance on the quality of primary schools.

Questionnaires were used to collect data in this research. The questionnaires were derived from libraries that supported the revealed variables. Based on the theories that have been presented in the previous chapter, it hence can be presented indicators of the research variables as follows.

Table 3.1 Instrument Specifications to Measure Principals' Leadership Style

\begin{tabular}{|c|c|c|c|}
\hline No & Variable & Indicator & Point \\
\hline \multirow[t]{8}{*}{1.} & \multirow{8}{*}{$\begin{array}{l}\text { The } \\
\text { principles' } \\
\text { leadership } \\
\text { style }\left(\mathrm{X}_{1}\right)\end{array}$} & a. Decision making & $2,13,23$ \\
\hline & & $\begin{array}{l}\text { b. Division of tasks } \\
\text { to subordinates }\end{array}$ & $\begin{array}{c}4,8,10,14,17, \\
25,27\end{array}$ \\
\hline & & c. $\quad$ Staff initiatives & $6,12,18,26$ \\
\hline & & 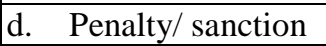 & $5,21,28,30$ \\
\hline & & 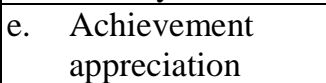 & $1,19,29$ \\
\hline & & f. Communication & 11,15 \\
\hline & & $\begin{array}{l}\text { g. Monitoring the } \\
\text { implementation } \\
\text { of task }\end{array}$ & $7,9,16$ \\
\hline & & h. Having meeting & $3,20,22,24$ \\
\hline \multicolumn{3}{|c|}{ Total of test elements } & 30 \\
\hline
\end{tabular}

Table 3.2 Instrument specifications to measure teachers' performance

\begin{tabular}{|c|c|c|c|}
\hline No & Variable & Indicators & Point \\
\hline \multirow[t]{4}{*}{1.} & \multirow[t]{4}{*}{$\begin{array}{l}\text { Teachers' } \\
\text { Performance } \\
\left(\mathrm{X}_{2}\right)\end{array}$} & $\begin{array}{llr}\text { a. } & \text { Ability } & \text { to } \\
\text { construct } & \text { lesson } \\
\text { plan } & \end{array}$ & $1-15$ \\
\hline & & \begin{tabular}{|lll} 
b. & Ability on \\
& learning process
\end{tabular} & $16-31$ \\
\hline & & $\begin{array}{lll}\text { c. } & \begin{array}{l}\text { Ability } \\
\text { learning } \\
\text { assessment }\end{array} & \\
\end{array}$ & $32-35$ \\
\hline & & $\begin{array}{ll}\text { d. Ability on } \\
\text { following up for } \\
\text { the assessment }\end{array}$ & $36-38$ \\
\hline \multicolumn{3}{|c|}{ Total of test elements } & 38 \\
\hline
\end{tabular}

The instrument specifications for measuring the principals' leadership style and teachers' performance were the conclusion of the theoretical indicator described in the previous chapter. Nevertheless, in the 
questionnaire, Adlan Adam study (2014) was adopted bythe researchers.

Table 3.3 Instrument Specification to Measure the Quality of Primary Schools

\begin{tabular}{|c|c|c|c|}
\hline No & Variable & Indicators & Point \\
\hline \multirow[t]{5}{*}{1.} & \multirow{5}{*}{$\begin{array}{l}\text { Quality of } \\
\text { Primary } \\
\text { Schools } \\
\text { (Y) }\end{array}$} & $\begin{array}{ll}\text { a. } & \text { Vision of } \\
& \text { Schools }\end{array}$ & $1,2,3,4,6,7$ \\
\hline & & $\begin{array}{ll}\text { b. } & \text { Teachers' } \\
& \text { community and } \\
\text { Educational } \\
\text { staff }\end{array}$ & 11 \\
\hline & & $\begin{array}{ll}\text { c. } & \text { Services for } \\
\text { external society }\end{array}$ & 5,12 \\
\hline & & $\begin{array}{ll}\text { d. } & \begin{array}{l}\text { Content of } \\
\text { Curriculum }\end{array}\end{array}$ & 8.9 \\
\hline & & e. Technology & 10 \\
\hline \multicolumn{3}{|c|}{ Total of test elements } & 12 \\
\hline
\end{tabular}

The parametric statistical technique was used to analyze the data. The parametric statistic according to Sugiyono (2013: 150) requires the fulfillment of many assumptions, the main assumption that the data are analyzed must be in subsequent normal distribution. Then,in the regression, the linierity assumptions should be fulfilled. SPSS 20 application was used in statistical calculations in this study.

\section{RESULT AND DISCUSSION}

1. The effect of Principals' Leadership Style (X1) on the Quality of Primary Schools (Y)

The results of the calculation showed that there was a significant effect on the principals' leadership style toward the quality of primary schools. This could be seen from the acquisition of calculation of $\mathrm{rx} 1 . \mathrm{y}=-0,227$ and $t$ count $>t$ table or $-2,306>1,984$. It meant that there was a significant and negative correlation between variables X1 to Y. The calculation results with SPSS 20 also proved that the significant value of 0.023 was smaller than 0.05. Simple regression equation showed $\mathrm{Y}=\mathrm{a}+\mathrm{bx}=47,38-0,169(\mathrm{X})$. The value of $b=-0.169$ meant that for each value of $\mathrm{X} 1$ was reduced one so the average value of $\mathrm{Y}$ reduced -0.169 . Therefore, based on the results, it can be concluded that the principals' leadership style affects the quality of primary schools.

The above calculation results are in line with the opinion of Edward Sallis (2012: 30) who states that one of the sources that affect the quality improvement is good and effective leadership. The implementation of the principals' leadership becomes a decisive factor in the educational process in schools. The educational leadership is not only played by the principal.

The big role of education will be realized if there is leadership cooperation in every level of policy making (Minister, General Director, Head of Department, and other stakeholders), so that they can focus on how to achieve optimal learning results for learners. Good and bad leadership is what the principal must understand as a leader.

The principals should have the right strategy to lead his subordinates in performing various tasks and functions as an educator. Understanding the style of leadership will increase the understanding of a principal as a school leader to himself, as well as to know the strengths and weaknesses that he has and can improve understanding of how he should treat his subordinates.

The results of the analysis about the effect of principals' leadership style on the quality of primary schools was in accordance with research of Tukiman, Cepi S. Abdul Jabar (2014). He states that to contribute at improving the quality of primary schools, the principals need to build mutual trust between teachers and employees, then mutual respect and respect each other will arise.

2. The Effect of Teachers' Performance (X2) on the Quality of Primary Schools (Y)

The results of the calculation showed that there was a significant effect on teachers' performance on the quality of primary schools. This can be seen from the calculation of rx2.y $=0,210$ and $\mathrm{t}$ count $>\mathrm{t}$ table or $2,118>1,984$. It meant there was a significant and positive correlation between variable of X2 to Y. The result of calculation with SPSS 20 also proved that significant value was equal to 0,037 or less than 0,05 . Simple regression showed the equation of $\mathrm{Y}=\mathrm{a}+\mathrm{bx}$ $=27.92+0.123(\mathrm{X})$. The value of $\mathrm{b}=0.123$ meant that for each value of $\mathrm{X} 1$ added one then the mean score of $\mathrm{Y}$ increased to 0.123 . Based on the result, it can be concluded that teachers' performance affects the quality of primary schools.

This study showed that the teachers' performance affects the quality of primary schools. The analysis results of teachers' performance affects toward primary schools' quality as stated by Edward Sallis (2012: 30). $\mathrm{He}$ mentions the sources in education that affect the quality improvement. One of them is a leading teacher. The role of teachers on the quality of primary schools lies in the learning process, as well as when the teachers 
perform tasks outside of teaching and learning.

Thus, in the field of education, teachers' performance is a factor affecting the quality of primary schools in Jatilawang subdistrict Banyumas district.

\section{The Effect of Principals' Leadership Style (X1) and Teachers' Performance (X2) on the Quality of Primary Schools (Y)}

Based on the calculation results, it could be known that $\mathrm{R}=0.303$ and $\mathrm{F}$ count $>$ F table or 4.868> 3.90. These results showed that there was a significant and positive effect between the principals' leadership style and the teachers' performance on primary schools' quality. The amount of contribution of leadership style variable of principles and teachers' performance toward primary schools' quality was $9,20 \%$ while the rests were equal to $90,8 \%$ determined by other factors through linear regression equation $=$ $37,14-0,169 \mathrm{X} 1+0,118 \mathrm{X} 2$. Because of the value of $b 1=-0.169$ and the value $b 2=$ 0.118 , it meant that for each value of $\mathrm{X} 1$ and $\mathrm{X} 2$ was added one then the value of $\mathrm{Y}$ increased to 47.50 .

The calculation result with SPSS 20 also showed $R=0,303$ and coefficient of determination ( $\mathrm{R}$ square) was equal to 0,092 . This showed that the quality of primary schools (Y) was affected by $9,20 \%$ by principals' leadership style and teachers' performance $(\mathrm{X} 1,2)$. From the results above, it can be concluded that the stronger the effect of principals' leadership style and teachers' performance, the stronger effect they contribute to the quality of primary schools. The results showed that there was a contribution between principals' leadership style and teachers' performance on primary schools' quality of $9.20 \%$. The rests were affected by other factors that were not discussed in this study.

Principals' leadership styles and teachers' performance are among the factors that affect a strong primary schools' quality, but there are still other influencing factors as described in Sallis's theory (2012: 30). It was mentioned that there are many sources in education that affect quality improvement such as good building facilities, high moral values, satisfactory of test results, specialization or vocation, parents' encouragement, business and local communities, abundant resources, the application of high technology, attention to learners and students, an adequate curriculum, or a combination of these factors.

From all the elements that affect the quality according to Sallis have their respective contributions in improving quality. The principals' leadership style and teachers' performance are only a small part in the elements that affect the rests of the quality improvement affected by other elements.

\section{Conclusion}

Based on the results of the statistical analysis that have been described in Chapter $\mathrm{IV}$, it can be drawn some conclusions as follows:

1. There is a significant effect of the principals' leadership style on the quality of primary schools in Jatilawang sub-distric of Banyumas regency. The form of the correlation can be written in the form of simple linear regression equation of $\mathrm{Y}=47,38-0,169(\mathrm{X} 1)$ and effective contribution of $5,15 \%$.

2. There is an effect of teachers' performance on the quality of primary schools in Jatilawang sub-district of Banyumas regency. The form of the correlation can be written in the form of simple linear regression equation $\mathrm{Y}=27.92$ +0.123 (X2) and effective contribution of $4.4 \%$.

3. There was an effect of principles' leadership style and teachers' performance toward the quality of primary schools in Jatilawang subdistrict, Banyumas regency. The form of simple linear regression equation is $\mathrm{Y}=37,14$ - $0,163(\mathrm{X} 1)+0,118(\mathrm{X} 2)$ and effective contribution of $9,20 \%$.

\section{References}

Adam, A. (2014). Pengaruh Gaya Kepemimpinan Kepala Sekolahterhadap Kinerja Guru SD Negeri Di Kecamatan Gondokusuma Daerah Istimewa Yogyakarta. Universitas Negeri Yogyakarta. Yogyakarta.

Arikunto, S. (2010). Prosedur Penelitian Suatu Pendekatan Praktik. Rineka Cipta. Jakarta.

Karawati, E dan Donni Juni Priansa. (2013). Kinerja Dan Profesionalisme Kepala Sekolah Membangun Sekolah Yang Bermutu. Bandung: Alfabeta.

Kerlinger, N.F, dan Pedhazur J. Elazar. (1987). Korelasi dan Analisis Regresi Ganda. Nurcahaya. Semarang. 
Mulyasa. (2013). Uji Kompetensi Dan Penilaian Kinerja Guru. Bandung: PT Remaja Rosdakarya.

Murwati, H. (2013). Pengaruh Serrtifikasi Profesi Guru Terhadap Motivasi Kerja Dan Kinerja Guru Di SMK Negeri Se-Surakarta. 1. (1). 1221.

Riduwan. (2009). Pengantar Statistika Sosial. Bandung: Alfabeta.

Riduwan. (2011) Belajar Mudah Penelitian Untuk Guru-Karyawan dan Peneliti Pemula. Bandung: Alfabeta.

Riduwan, A. Rusyana dan Enas. (2011). Cara Mudah Belajar SPSS Versi 17.0 dan Aplikasi Statistik Penelitian. Bandung: Alfabeta.

Rosdianti R.S. (2013). Studi Deskriptif Pada Sekolah Menengah Kejuruan Swasta Di Kota Bandung. 3. (1). 93-134.

Sallis, E. (2012). Total Quality Management In Education Manajemen Mutu Pendidikan. Yogyakarta: IRCiSoD.

Singarimbun, M. dkk. (1989). Metode Penelitian Survei. PT Pustaka LP3ES. Jakarta.

Sudjana. (1996). Teknik Analisis Regresi Dan Korelasi Nagi Para Peneliti. Bandung: Tarsito

Sugiyono. (2013). Statistik Untuk Penelitian. Alfabeta. Bandung.

Sugiyono. (2013). Metode Penelitian Kuantitatif, kualitatif, dan $R \& D$. Alfabeta. Bandung.

Susanto, A. (2013). Teori Belajar Dan Pembelajaran Di Sekolah Dasar. Jakarta: Kencana.
Suti, M. (2011).Strategi Peningkatan Mutu Di Era Otonomi Pendidikan. 3. (2).

Sukardi. (2007). Metodologi Penelitian Pendidikan. PT Bumi Aksara. Jakarta.

Tukiman, Jabar Abdul C.S. (2014). Implementasi Kepemimpinan Transformasi Kepala Sekolah Dalam Meningkatkan Mutu Sekolah Di SD Kanisius Sengkan Kabupaten Sleman. Jurnal Akuntabilitas Manajemen Pendidikan. 2. (1). 121-134.

UU Nomor. 19 Tahun 2005 tentang Standar Nasional Pendidikan.

UU Nomor. 22 Tahun 1999 tentang Otonomi Pemerintah Daerah.

Wahjusumidjo. (2008). Kepemimpinan Kepala Sekolah Tinjauan Teoritik Dan Permasalahannya. Jakarta: PT Raja Grafindo Persada.

Mutu Pendidikan Indonesia Terendah di Dunia.[online]. Tersedia: http://nasional.tempo.co/read/news/2013/12/0 6/173535256/mutu-pendidikan-indonesiaterendah-di-dunia

Sriyanto. (2015). Mutu Sekolah Berdasarkan Kreativitas Dan Budaya Kerja Guru. Jurnal Dinamika Pendidikan Dasar Vol 7: No.2.

Sumarno. (2009). Pengaruh Kepemimpinan Kepala Sekolah dan Profesionalisme Guru Terhadap Kinerja Guru Sekolah Dasar Negeri Di Kecamatan Paguyangan Kabupaten Brebes. Universitas Negeri Semarang. 